KS. JAN DOHNALIK

Wydział Prawa Kanonicznego

Uniwersytetu Kardynała Stefana Wyszyńskiego Warszawie

ORCID: 0000-0003-0674-2921

\title{
ORDYNARIAT POLOWY A ORDYNARIAT PERSONALNY DLA BYŁYCH ANGLIKANÓW - PODOBIEŃSTWA I RÓŻNICE
}

Treść: Wstęp. - 1. Rys historyczny. - 2. Ordynariat polowy jako model ordynariatu dla byłych anglikanów. - 3. Nowe rozwiązania prawne w ordynariacie personalnym dla wiernych pochodzących z anglikanizmu. - Wnioski.

\section{Wstęp}

Celem niniejszego studium jest porównanie od strony prawnej dwóch jurysdykcyjnych struktur personalnych: ordynariatów polowych (lub wojskowych) oraz ordynariatów personalnych dla wiernych wywodzących się z anglikanizmu. Inspiracją do przeprowadzenia takich badań porównawczych jest refleksja wybitnego kanonisty Gianfranco Ghirlandy, która znalazła się na stronie internetowej Kongregacji Doktryny Wiary, jako półoficjalny komentarz do konstytucji apostolskiej Anglicanorum coetibus, przez którą Benedykt XVI ustanowił ramy prawne dla funkcjonowania ordynariatów personalnych dla byłych anglikanów. Ghirlanda napisał:

„Możliwość powołania ordynariatów personalnych dla anglikanów wchodzących do pełnej jedności z Kościołem Katolickim, która jest przewidziana w apostolskiej konstytucji Anglicanorum Coetibus nie tworzy nowej struktury pośród obowiązujących norm kanonicznych, ale raczej używa struktury ordynariatów personalnych, pierwotnie stworzoną dla duszpasterstwa członków sił zbrojnych, 
w Konstytucji Apostolskiej Jana Pawła II Spirituali Militum Curae z 21 kwietnia 1986. Pomimo podobieństw między dwoma typami ordynariatów personalnych, jest jasne, że ze względu na ich różne cele - jeden ordynariat dla wojska a drugi dla tych przybywających $\mathrm{z}$ anglikanizmu - istnieją też znaczące różnice między nimi. Zajmujemy się strukturami utworzonymi przez Kościół, aby ogarnąć specyficzne sytuacje, które wynikają z potrzeb wiernych i które są wyjątkowe z definicji. Troska duszpasterska Kościoła i elastyczność jego norm kanonicznych pozwala na tworzenie struktur prawnych, które są szczególnie odpowiadające duchowemu dobru wiernych, jednocześnie nie przecząc podstawowym zasadom katolickiej eklezjologii”'.

Choć istnieje pokaźna literatura dotycząca ordynariatów polowych ${ }^{2}$ i pojawiło się już także kilka znaczących prac na temat ordynariatów personalnych dla wiernych pochodzących $z$ anglikanizmu ${ }^{3}$, brakuje

\footnotetext{
${ }^{1}$ G. GHirlanda, The significance of the apostolic constitution Anglicanorum coetibus, w: http://www.vatican.va/roman_curia/congregations/cfaith/documents/ rc_con_cfaith_doc_20091104_article-fr-ghirlanda_en.html [30.12.2018] (tłumaczenie własne).

${ }^{2}$ Zob. E. BAura, Legislazione sugli Ordinariati Castrensi, Milano 1992; T. PŁoski, Duszpasterstwo w Wojsku Polskim. Studium prawne z uwzględnieniem praw człowieka i prawa humanitarnego, Olsztyn 2006; A. VIAnA, Territorialidad y personalidad en la organización eclesiástica. El caso de los ordinariatos militares, Servizio de publicaciones de la universidad de Navarra, Pamplona 1992; E. Busato, La Chiesa, lo stato e i militari. Studio comparato fra l'ordinamento canonico e quello italiano, Padova 1992; Dieci Anni Dopo la promulgazione della Costituzione Apostolica „Spirituali Militum Curae". Atti del Simposio internazionale degli ordinariati militari Buenos Aires - Argentina 4-8 settembre 1996, Città del Vaticano 1996; J.M.R. Esposito Mpazay INo, L'ordinariat militaire dans la nouvelle legislation canonique. Interpretation et application des canons 368, 369, 372, 569 e 289 au Rwanda, Romae 1999; J.O. Contreras Sarmiento, La „Spirituali Militum Curae” Aplicación juridíca y efficacia pastoral, Romae 2008; J. DohnAlik, Działalność duszpasterska Ordynariatu Polowego. Aspekty prawno-kanoniczne, w: Konkordat: ocena z perspektywy 15 lat obowiązywania, red. J. Krzywda, P. Kroczek, Kraków 2014 (Annales Canonici Monographiae nr 2), s. 119-141.

${ }^{3}$ Zob. P. Majer, Nowa hierarchiczna struktura $w$ Kościele łacińskim. Konstytucja apostolska Anglicanorum coetibus z 4 XI 2009 roku, w: Ars boni et aequi. Ksiega pamiątkowa dedykowana Księdzu Profesorowi Remigiuszowi Sobańskiemu z okazji
} 
badań porównawczych nad obiema strukturami, które ukazałyby podobieństwa i różnice między nimi ${ }^{4}$. To niewielkie studium ma za zadanie wypełnić tę lukę oraz ukazać wnioski dotyczące przyszłości i znaczenia hierarchicznych struktur personalnych.

\section{Rys historyczny}

W XX wieku pierwszy wikariat polowy został utworzony przez papieża Piusa X w 1910 roku dla Chile 5 . Instrukcja Kongregacji Konsystorialnej Sollemne Semper ${ }^{6}$ dotycząca wikariatów polowych w całym Kościele ukazała się dopiero w roku 1951, za pontyfikatu Piusa XII. W tym okresie bardzo wiele wikariatów polowych zostało założonych w różnych krajach świata, natomiast art. 14 konkordatu laterańskiego z 1929 roku używa sformułowania „ordynariusz wojskowy” (ordinario militare $)^{7}$.

osiemdziesiątej rocznicy urodzin, red. J. Wroceński, H. Pietrzak, Warszawa 2010, s. 355-356; G. Ghirlanda, La Costituzione Apostolica Anglicanorum Coetibus, Periodica 99 (2010) s. 373-430; J.I. ArRIETA, Gli ordinariati personali, Ius Ecclesiae 22 (2010), s. 151-172; G. RUGGIERI (red.), La Costituzione „Anglicanorum coetibus” e l'ecumenismo, Bologna 2012; P. ZAJĄc, Status prawny Ordynariatów personalnych dla anglikanów powracających do pełnej wspólnoty z Kościołem Katolickim, Lublin 2017.

${ }^{4}$ Zarys takiego porównania, dotyczący upodobnienia obu struktur do diecezji znajdujemy w cytowanym na początku tego artykułu tekście Gianfranco Ghirlandy, a także w kolejnym przytoczonym artykule tego autora por. G. GHIRLANDA, La Costituzione Apostolica..., s. 390-391. Autor niniejszego studium zaznajomił się także z niepublikowaną dotychczas pracą licencjacka T. Smalcerza, w której obie struktury zostały w pewnym wymiarze porównane, por. T. SMALCERz, Circoscrizioni Ecclesiastiche Personali come strutture giuridiche assimilate alla diocesi, Roma 2012.

${ }^{5}$ Por. Pius X, Motu proprio In hac Beatissimi Petri Cathedra, 3.05.1910, AAS 2 (1910), s. 501-503. Zob. E. BAura, Legislazione sugli Ordinariati..., s. 4.

${ }^{6}$ Zob. Sacra Congregatio Consistoriale, Instr. Sollemne Semper, AAS 43 (1951), s. 562-565.

${ }^{7}$ Por. Concordato del 1929, art. 13: “[...] L’Ordinario Militare sarà rivestito dalla dignità arcivescovile"; art. 14: "I Cappellani militari hanno, riguardo a dette truppe, competenze parrocchiali. Essi esercitano il Sacro Ministero sotto la giurisdizione dell’Ordinario Militare assistito dalla propria curia". Zob. E. Busato, La Chiesa, 
Równolegle powstawały ordynariaty obejmujące wiernych obrządku wschodniego na terenach na których nie mieli swojej hierarchii ${ }^{8}$. Za pontyfikatu Piusa X, w latach 1912-1914 zostały utworzone hierarchiczne struktury bezpośrednio podległe Stolicy Apostolskiej dla Rusinów obrządku wschodniego w USA oraz w Kanadzie ${ }^{9}$. Później, od pierwszych lat pontyfikatu Piusa XII, używano nazwy ordynariatu w odniesieniu do kolejnych struktur kościelnych tworzonych przez Stolicę Apostolską ${ }^{10}$, w których łaciński ordynariusz - najczęściej biskup stolicy lub prymas - obejmował opieką duszpasterską katolików obrządków wschodnich nie posiadających własnego ordynariusza ${ }^{11}$.

lo stato e i militari. Studio comparato fra l'ordinamento canonico e quello italiano, Padova 1992, s. 149-174.

${ }^{8}$ Zob. G.P. MonTini, La territorialità della Chiesa patriarcale (can. $78 \$ 2$ CCEO). Il presupposto degli ordinariati per ifedeli orientali in territorio latino, Quaderni di Diritto Ecclesiale (QDE), s. 10-15; F. MARTI, Gli ordinariati per i fedeli di rito orientale: una ricostruzione storico-giuridica, QDE 2015/1, s. 16-38.

${ }^{9}$ Por. Pius X, Litt. Ap. Officium supremi Apostolatus, 15.07.1912, AAS 4 (1912), s. 555-556; Sacra Congregatio De Propaganda Fide Pro Negotils Ritus orienTALIs, Decretum De spirituali administratione Ecclesiae Graeco-Ruthenae in Foederatis Civitatibus Americae Septentrionalis, 17.08. 1914, AAS 6 (1914), s. 458-463. Pierwszy z wyżej wymienionych dokumentów dotyczy Kanady, natomiast drugi Stanów Zjednoczonych Ameryki. W dekrecie Kongregacji wspomniane jest nadanie biskupowi grecko-rusińskiemu w USA pełnej i zwyczajnej jurysdykcji już w 1912, jednak dokumentacja odnośnie do erygowania tej struktury pozostaje niedostępna. Należy zauważyć, że w przytoczonych dokumentach nigdzie nie jest użyte wprost ordynariat, ale mowa raczej o ordinaria iurisdictio, jednak w literaturze jest mowa o erygowaniu ordynariatów dla katolików obrządku grecko-katolickiego w tych krajach. Zob. F. MARTi, Gli ordinariati..., s. 20-22.

${ }^{10}$ Por. Sacra Congregatio pro Ecclesia Orientali, Decretum Ordinariatus in Brasilia constituitur pro fidelibus rituum orientalium, 14.11. 1951, AAS 44 (1952) s. 382-383; IDEM, Decretum Ordinariatus pro omnibus fidelibus rituum orientalium in Gallia degentibus insituitur, 27.07.1954, AAS 47 (1955), s. 612-613. W sprawie ukształtowania i doprecyzowania pojęcia ordynariatu dla katolików obrządku wschodniego zob. F. MARTI, Gli ordinariati..., s. 28-37.

${ }^{11}$ Do dzisiaj istnieje sześć takich ordynariatów (nie licząc trzech obejmujących z definicji wyłącznie wiernych obrządku ormiańskiego): we Francji, w Argentynie, w Brazylii, w Austrii, w Polsce, a od 2016 także w Hiszpanii. Por. Annuario Pontificio per l'Anno 2018, Città del Vaticano 2018, Esarcati apostolici e ordinari per fedeli di 
Sobór Watykański II w dekretach Presbyterorum Ordinis ${ }^{12}$ oraz Christus Dominus ${ }^{13}$ zachęcał do tworzenia ponaddiecezjalnych personalnych struktur hierarchicznych. Szczególnie wikariaty polowe cieszyły się uznaniem ojców soborowych ${ }^{14}$. W czasie prac nad reformą Kodeksu prawa kanonicznego sformułowano 8 zasadę rewizji kodeksu, w której podkreślono wagę personalnej jurysdykcji, przy pozostawieniu ogólnego założenia terytorialnego przyporządkowania wiernych ${ }^{15}$. W obowiązującym Kodeksie prawa kanonicznego z 1983

rito orientale, s. 1018-1022. Zob. także A. KAPTIJN, Gli ordinariati per i fedeli cattolici orientali privi della gerarchia propria, w: P. Gefaell (red.), Cristiani Orientali e Pastori Latini, Milano 2012, s. 234-267.

${ }^{12}$ Por. SовóR WAтүкаŃski II, Dekret o posłudze i życiu prezbiterów Presbyterorum Ordinis, nr 10: „Gdzie domagałyby się tego racje apostolstwa, należy ułatwić nie tylko właściwe rozmieszczenie prezbiterów, ale także trzeba zorganizować specjalne dzieła duszpasterskie dla różnych grup społecznych, w niejednym regionie lub narodzie, czy też w każdej części świata. W tym więc celu można z pożytkiem utworzyć seminaria międzynarodowe, specjalne diecezje lub prałatury personalne i inne tego rodzaju instytucje, do których dla wspólnego dobra Kościoła można przeznaczaćlub inkardynować prezbiterów w sposób, który zostanie określony dla każdego z tych przedsięwzięć i zawsze z zachowaniem praw miejscowych ordynariuszy", w: SoвóR Waty Kański II, Konstytucje. Dekrety. Deklaracje, Poznań 2002, s. 493.

${ }^{13}$ Por. Soвór Waty kAŃski II, Dekret o pasterskich zadaniach biskupów w Kościele Christus Dominus, nr 42: „Jest rzeczą wskazaną, by do obsługi wszystkich lub kilku diecezji jakiegoś określonego okręgu albo narodu, ustanowiono pewne stanowiska, które można powierzyć również biskupom. Święty Sobór poleca więc, aby między przełożonymi lub biskupami pełniącymi te zadania a biskupami diecezjalnymi i konferencjami biskupów utrzymywała się zawsze braterska wspólnota i zgodne działanie w wypełnianiu duszpasterskich zadań; jej zasady winny być także określone prawem ogólnym", w: Sobór WaTy Kański II, Konstytucje..., s. 257.

${ }^{14}$ Por. Tamże, nr 43: „Ponieważ o duchową opiekę nad żołnierzami, z powodu specyficznych warunków ich życia, należy się szczególnie zatroszczyć, w każdym kraju trzeba utworzyć, w miarę możliwości, wikariat polowy. Tak wikariusz, jak i kapelani winni się poświęcić temu trudnemu dziełu z oddaniem, zgodnie współpracując z biskupami diecezjalnymi”.

${ }^{15}$ Por. Pontificia Commssio Codici Iuris Canonici Recognoscendo, Principia quae Codicis Iuris Canonici recognitionem dirigant a pontificia commissione proposita et primi generalis coetus "Synodi episcoporum» examini subiecta, Typis Polyglottis Vaticanae 1967, nr 8, s. 15: „Ex documentis conciliaribus videtur deducendum 
roku skutki tej zasady wydają są ograniczone do kilku kanonów, dotyczących prałatur personalnych ${ }^{16}$, personalnych Kościołów partykularnych przyrównanych do diecezji $1^{17}$, oraz parafii i proboszczów personalnych ${ }^{18}$. Natomiast duszpasterstwo wojskowe zostało jedynie wspomniane w kanonie, który odsyła do pozakodeksowego prawodawstwa: „Kapelani wojskowi rządzą się właściwymi ustawami”19.

Przełomowe normy regulujące funkcjonowanie ordynariatów polowych lub wojskowych ${ }^{20}$, zostały zawarte kilka lat później w Konstytucji Apostolskiej Spirituali militum curae z 1986 roku ${ }^{21}$. Po jej opublikowaniu powstały Statuty ponad trzydziestu ordynariatów polowych $^{22}$. Natomiast po 1986 roku Stolica Święta nie ustanawiała

principium: finem pastoralem dioeceseos et bonum totius Ecclesiae catholicae claram et congruentem circumscriptionem territorialem exigere, ita ut, ex iure ordinario, uniuscuiusque dioecesis unitas organica in tuto ponatur quoad personas, officia, instituta ad instar corporis apte viventis. Videtur ex alia parte, ob exigentias moderni apostolatus, sive in ambitu alicuius nationis vel regionis sive intra ipsum territorium dioecesanum ampliori ratione sanciri posse et forsitan debere, saltem ex iure extraordinario in ipso Codice inscripto, unitates iurisdictionales ad peculiarem curam pastoralem destinatas, quarum exempla exstant plura in hodierna disciplina".

${ }^{16}$ Por. kan. 294-297 KPK.

${ }^{17}$ Por. kan. $372 \$ 2$ KPK: „Jednakże tam, gdzie zdaniem najwyższej władzy kościelnej, po wysłuchaniu opinii zainteresowanych Konferencji Episkopatu, okaże się to pożyteczne, mogą być na tym samym terytorium erygowane Kościoły partykularne odrębne z racji obrządku wiernych lub innej podobnej racji”.

${ }^{18}$ Por. kan. 518 KPK: „[...] Gdzie jednak jest to wskazane, należy tworzyć parafie personalne, określone z racji obrządku, języka, narodowości wiernych jakiegoś terytorium, albo z innego jeszcze powodu". Zob. też kan. 813 oraz kan. 1110 KPK.

${ }^{19}$ Kan. 569 KPK.

${ }^{20}$ Konstytucja Apostolska używa obu tych pojęć, z powodów stylistycznych w niniejszym studium będą zamiennie używane pojęcia ordynariatów polowych i ordynariatów wojskowych, jako mających to samo znaczenie.

${ }^{21}$ Por. Ioannes Paulus II, Costitutio Apostolica Spirituali Militum Curae, 21.04.1986, AAS 78 (1986), s. 481-486. Tekst polski: JAN PAwe£ II, Konstytucja Apostolska Spirituali Militum Curae, „Osservatore Romano”, wyd. polskie, 7(1986), nr 4, s. 32 (dalej będzie dla tego dokumentu stosowany skrót SMC).

${ }^{22}$ Por. E. Baura, Legislazione sugli Ordinariati Castrensi, Milano 1992. Po opublikowaniu tej książki powstało jeszcze kilka ordynariatów polowych, których statuty zazwyczaj można odnaleźć w Acta Apostolicae Sedis. 
nowego typu struktur personalnych, z wyjątkiem personalnej administratury apostolskiej św. Jana Marii Vianney’a w Campos ${ }^{23}$. Kolejny przełom nastąpił dopiero 4 listopada 2009 roku, kiedy Benedykt XVI utworzył możliwość erygowania ordynariatów personalnych dla wiernych wywodzących się z tradycji anglikańskiej, wydając konstytucję apostolską Anglicanorum Coetibus ${ }^{24}$, a także normy uzupełniające ${ }^{25}$. Od tego czasu zostały utworzone trzy ordynariaty personalne dla wiernych pochodzących z anglikanizmu ${ }^{26}$ : na terenie Anglii i Walii, USA oraz Australiii ${ }^{27}$.

${ }^{23}$ Por. Congregatio pro Epicopis, Decretum De Administratione Apostolica personali «Sancti Ioannis Mariae Vianney " condenda, AAS 94 (2002), s. 305-308. Administratura powstała dla ściśle określonej grupy wiernych wywodzących się ze struktur związanych ze schizmą abp. Marcela Lefebvre'a na terenie zaledwie jednej diecezji brazylijskiej, jednak w jej statutach znajduje się wiele elementów podobnych do ordynariatów polowych, a także parę nowatorskich rozwiązań kanonicznych. Zob. J. Bednarz, Administratura Apostolska Personalna „Św. Jana Marii Vianney'a”, Annales Canonici 2005 (1), s. 139-175.

${ }^{24}$ Por. Benedictus XVI, Costitutio Apostolica Anglicanorum Coetibus, 4.11.2009, AAS 101 (2009), s. 985-990. Tekst polski: BenEDy KT XVI, Konstytucja Apostolska Anglicanorum Coetibus, „Ossevatore Romano” wyd. polskie, 1 (319) 2010, s. 11-13 (Dalej będzie stosowany dla tego dokumentu skrót AC).

${ }^{25}$ Por. Congregatio Pro doctrina fidei, Normae Complementares Constitutioni Apostolicae «Anglicanorum Coetibus», w: „Communicationes” 51 (2019)/1, s. 101-116. W niniejszym przedłożeniu znajdują się odnośniki do tego obowiązującego tekstu opublikowanego w 2019 roku. Ponieważ dotychczas tekst norm komplementarnych nie został opublikowany w oficjalnym biuletynie Stolicy Apostolskiej jakim jest „Acta Apostolicae Sedis”, będzie on cytowany za pismem Rady ds. Tekstów Prawnych, jakim jest „Communicationes”. Na przytoczonych stronach tego czasopisma znajduje się wersja włoska oraz angielska norm, w niniejszym artykule będzie cytowana wersja angielska, jako bardziej praktyczna w tematyce ordynariatu dla wiernych pochodzących z anglikanizmu. W dalszej części przedłożenia na oznaczenie tego dokumentu będzie stosowany skrót NC.

${ }^{26} \mathrm{~W}$ dalszej części niniejszego studium ordynariaty personalne dla wiernych wywodzących się z anglikanizmu będą nazywane po prostu ordynariatami personalnymi.

${ }^{27}$ Por. Annuario Pontificio per l'Anno 2018, Città del Vaticano 2018, Ordinariati Personali, s. 1023. 


\title{
2. Ordynariat polowy jako model ordynariatu personalnego dla byłych anglikanów
}

\begin{abstract}
Ordynariaty polowe są hierarchicznymi strukturami personalnymi, które "pod względem prawnym zostają upodobnione do diecezji”28. Konstytucja Apostolska Anglicanorum Coetibus używa podobnej formuły względem ordynariatów personalnych: „Każdy Ordynariat [...] pod względem prawnym jest przyrównany do diecezji" ${ }^{29}$. W związku z przyrównaniem do diecezji oba ordynariaty mogą być postrzegane jako Kościoły partykularne ${ }^{30}$, do których definicji nie należy terytorialnośćc ${ }^{31}$. Oznacza to, że zarówno do ordynariatów polowych, jak
\end{abstract}

\footnotetext{
${ }^{28}$ SMC art. I $\$ 1$. Takiego sformułowania nie znajdujemy w normach kanonicznych w odniesieniu do wcześniej istniejącej struktury personalnej, jaką jest prałatura personalna. Zob. kan. 294-297 KPK.

${ }^{29} \mathrm{AC}$ art. I $\$ 3$. Ten artykuł Konstytucji Apostolskiej jest opatrzony przypisem nr 12, w którym prawodawca wyraźnie odsyła do pierwszego artykułu konstytucji apostolskiej Spirituali Militum Curae. Zob. także G. GHIrLanda, La Costituzione Apostolica..., s. 390.

${ }^{30}$ Ghirlanda poddaje przekonywujące argumenty za tym, że Ordynariat Polowy
} jest kościołem partykularnym w przeciwieństwie do prałatury personalnej, natomiast inaczej uważa A. Viana. Podobna dykusja toczy się wokół ordynariatu personalnego, gdzie Arrieta oraz Majer bronią stanowiska, że nie jest to kościół partykularny, ale struktura komplementarna. Jednak Ghirlanda, pokazuje przekonujące argumenty za tym, że zarówno ordynariat polowy, jak i ordynariat personalny dla byłych anglikanów realizuje kan. $372 \$ 2$ KPK i podkreśla pełny wymiar eklezjalny obu instytucji. To rozumowanie popiera P. Zając, autor polskiej monografii na temat ordynariatów personalnych. Por. A. VianA, Territorialidad y personalidad..., s. 278-288; J.I. Arrieta, Gli ordinariati..., s. 159-161; P. MAJer, Nowa hierarchiczna struktura..., s. 359-361; G. GHIRlAndA, La Costituzione Apostolica..., s. 392-394; P. ZAJĄC, Status prawny Ordynariatów..., s. 219: „odpowiadając na postawione we wstępie pytanie o status ordynariatów personalnych dla anglikanów w prawie Kościoła łacińskiego należy jednoznacznie stwierdzić, iż należą one do Kościołów partykularnych".

${ }^{31}$ Por. kan. 372 KPK. Warto w tym miejscu przypomnieć, że przy redakcji Kodeksu prawa kanonicznego w latach 1977-1980 proponowano termin praelaturae catrenses i umieszczenie struktur duszpasterstwa wojkkowego w kanonach o prałaturach personalnych. Jeszcze schemat przyszłej Konstytucji Apostolskiej z 1985 roku nazywał się „De Praelaturis militaribus”. Jednak ostatecznie zdecydowano się na nazwę Ordinariatus Catrensis seu militaris, która nie odwołuje się wprost do kan. 372 
i do ordynariatów personalnych stosują się normy prawne Kodeksu odnoszące się do diecezji, jednak z dwoma zastrzeżeniami: przepisów specjalnych zawartych w prawodawstwie dla ordynariatów oraz różnic, jakie wynikają z natury powyższych struktur oraz ich specyfiki. Z przyrównania do diecezji wynika między innymi obowiązek złożenia co pięć lat Stolicy Świętej odpowiedniego raportu o stanie ordynariatu, a także udanie się w tym samym odstępie czasu do Rzymu w ramach wizyty Ad limina apostolorum, o czym mówią obie konstytucje apostolskie, właściwe dla obu rodzajów ordynariatów ${ }^{32}$. Ponadto zarówno biskupi polowi, jak i ordynariusze dla byłych anglikanów są z urzędu członkami konferencji episkopatu, na terenie których znajduje się ich siedziba ${ }^{33}$. W obu przypadkach prawodawca wyraźnie wzywa do współdziałania i wzajemnego uzupełniania w działalności duszpasterskiej ordynariatów i diecezji terytorialnych ${ }^{34}$.

Władza Ordynariusza polowego jest personalna, czyli sprawowana względem konkretnych osób. Osoby te wymienione są w Konstytucji Apostolskiej Spirituali Militum Curae ${ }^{35}$, a także w Statutach poszczególnych ordynariató $w^{36}$. Są to ludzie z różnych ty tułów związani z wojskiem, czyli przede wszystkim żołnierze oraz ich rodziny, ale także pracownicy resortu obrony narodowej, uczniowie szkół wojskowych czy personel i pacjenci wojskowych szpitali ${ }^{37}$. Podobnie władza ordy-

$\$ 2$ Kodeksu prawa kanonicznego, ale pozwala na uznanie ordynariatu za Kościół partykularny, w przeciwieństwie do prałatury personalnej. Por. J.M.R. Esposito Mpazayino, L'ordinariat militaire..., s. 111-114.

${ }^{32}$ Por. SMC art. XII; AC art. XI; KPK, kan. 399-400. Zob. J.M. R. EsPosito MPAZAYINO, L'ordinariat militaire dans la nouvelle legislation canonique..., s. 52-53.

${ }^{33}$ Por. SMC, art. III; NC, art. $2, \S 2$ : „The Ordinary is a member of the respecibe Episcopal Conference".

${ }^{34} \mathrm{SMC}$ art. IV c); art. V; AC art. 5 lit. c); NC art. $5 \$ 4$. Por. A. VIAnA, Territorialidad y personalidad..., s. 289-298.

${ }^{35}$ Por. SMC art. X.

${ }^{36}$ Zob. E. Baura, Legislazione sugli Ordinariati Castrensi, Giuffrè editore, Milano 1992, s. 73-378.

${ }^{37}$ Por. Kongregacja Ds. Biskupów, Statut Ordynariatu Wojskowego czyli Polowego w Polsce (dalej: Statut Ordynariatu Polowego w Polsce), „Osservatore Romano”, wyd. polskie, 12 (1991) nr 3, s. 56. 
nariusza dla byłych anglikanów jest personalna, czyli „sprawowana nad wszystkimi, którzy należą do Ordynariatu”38. Obejmuje ona tych, którzy znaleźli się w pełnej komunii z Kościołem Katolickim dzięki posłudze duszpasterskiej personalnego ordynariatu, przyjęli tam przynajmniej niektóre sakramenty inicjacji chrześcijańskiej, lub są rodzinnie związani z wiernymi ordynariatu dla byłych anglikanów ${ }^{39}$.

Kolejne podobieństwo między dwoma typami ordynariatów dotyczy możliwości inkardynacji duchownych, zgodnie z normami prawa kanonicznego ${ }^{40}$. Jedną z możliwych dróg jest wychowanie własnych alumnów, którzy przyjmują święcenia kapłańskie dla posługi w ordynariacie personalnym ${ }^{41}$ albo w ordynariacie polowym ${ }^{42}$.

Ponadto, zarówno kapelani wojskowi odnośnie do powierzonych im wiernych, jak i proboszczowie parafii personalnych ordynariatu personalnego dla byłych anglikanów mają uprawnienia i obowiązki proboszczów ${ }^{43}$. Są więc zobowiązani powadzić księgi parafialne, oraz prowadzić działalność duszpasterską zgodnie z wytycznymi konferencji episkopatu danego kraju. W obu omawianych strukturach zakłada się też współpracę z lokalną parafią diecezjalną. W ordynariacie polowym żołnierz, który zamieszkuje parafię terytorialną przynależy do niej, a jednocześnie jest pod opieką duszpasterską kapelana wojskowego, co nazywa się jurysdykcją kumulatywną ${ }^{44}$.

${ }^{38} \mathrm{AC}$ art. V nr C).

${ }^{39}$ Por. AC art. I $₫ 4$; NC art. $5 \$ 1-2$. Możliwość przynależności do Ordynariatu dla tych, którzy zostali ochrzczeni w Kościele katolickim, pozostawili praktykę wiary, a potem do niej powrócili dzięki misji ordynariatu i w nim przyjęli pozostałe sakramenty została udzielona przez papieża Franciszka, który zaaprobował dodanie paragrafu drugiego do 5 artykułu Norm uzupełniających dnia 31 maja 2013 roku por. „Communicationes” 51 (2019)/1, s. 110, przypis nr 1.

${ }^{40}$ Por. SMC art. VI $\$ 3-4 ; \mathrm{AC}$ art. VI $\$ 3$.

${ }^{41}$ Por. AC art. VI $\$ 3, \S 5$; NC art. 10.

${ }^{42}$ Por. SMC art. VI $\$ 3$.

${ }^{43}$ Por. AC art. VIII $\$ 2$; SMC art. VII. Odnośnie kapelanów wojskowych cytowany artykuł zawiera klauzulę, która ogranicza te prawa, jeśli „z samej natury rzeczy albo ze statutów partykularnych wynika co innego".

${ }^{44}$ Por. SMC art. 4: „Jurysdykcja ordynariusza polowego jest [...] 3. własna, ale złączona (cumulativa) z jurysdykcją biskupa diecezjalnego, bowiem osoby należące 
W ordynariacie dla byłych anglikanów wierny przynależy jedynie do parafii lub parafii tymczasowej tego ordynariatu, jednak współdziała w konkretnych dziełach charytatywnych lub duszpasterskich i wtedy władza proboszcza terytorialnego jest sprawowana w sposób łączny z proboszczem personalnym, „przy wzajemnej pomocy duszpasterskiej" ${ }^{45}$. Ponadto w razie przeszkody w działaniu dla duszpasterza dla byłych anglikanów, proboszcz diecezji terytorialnej może pełnić posługę w parafii personalnej na zasadzie uzupełniającej ${ }^{46}$.

Na zakończenie tej części rozważań warto zauważyć, że prawodawstwo dotyczące obu typów ordynariatów jest też podobne od strony formalnej. Obie badane struktury rządzą się własnymi normami o charakterze ramowym (konstytucje apostolskie Spirituali Militum Curae i Anglicanorum Coetibus, w przypadku byłych anglikanów także normy uzupełniające), własnymi statutami lub normami szczegółowymi poszczególnych ordynariatów oraz powszechnym prawem kościelnym ${ }^{47}$.

\section{Nowe rozwiązania prawne $w$ ordynariatach personalnych w relacji do ordynariatów polowych}

Różnice między ordynariatami polowymi a ordynariatami personalnymi dla byłych anglikanów wyrastają z różnych celów, jakim służą te instytucje. Ordynariaty polowe czyli wojskowe mają za cel duszpasterską troskę o żołnierzy i ich rodziny, zarówno w czasie pokoju, jak i kryzysu czy wojny ${ }^{48}$. Opieka duszpasterska wobec

do ordynariatu pozostają ściśle związane także z Kościołem partykularnym, do którego należą $\mathrm{z}$ tytułu zamieszkania lub obrządku”.

${ }^{45} \mathrm{AC}$ art. $8 \$ 2$; Por. NC art. $5 \$ 4$.

${ }^{46}$ Por. NC Art. $14 \$ 2$.

${ }^{47}$ Por. AC art. II. Statut Ordynariatu Wojskowego czyli Polowego w Polsce, nr 2: „Ordynariat Polowy rządzi się: a) Konstytucją Apostolską Spirituali Militum Curae z dnia 21 kwietnia 1991 roku (AAS 78/1986, s. 481-486); b) przepisami Kodeksu Prawa Kanonicznego; c) niniejszym Statutem nadanym przez Stolicę Świętą".

${ }^{48}$ Prawdopodobnie tutaj ma źródło specjalne prawo zawarte w Statucie Ordynariatu Polowego w Polsce, według którego w razie sede vacante administratorem ordynariatu zostaje automatycznie wikariusz generalny, co jest niezgodne z prawem 
ludzi w mundurach wymaga spójnej, ale i elastycznej pod względem prawnym struktury, która pozwoli na dostosowanie się do szybko zmieniających się okoliczności ${ }^{49}$. Tymczasem ordynariat personalny dla byłych anglikanów został stworzony z myślą o umożliwieniu włączenia w pełną komunię z Kościołem katolickim wiernych będących uprzednio członkami wspólnoty Kościoła anglikańskiego. Celem tego ordynariatu jest więc z jednej strony zagwarantowanie jedności wiary katolickiej oraz uwypuklenie więzi z papieżem, z drugiej strony troska, aby pozostały „żywe tradycje duchowe, liturgiczne i duszpasterskie Wspólnoty anglikańskiej" ${ }^{50}$. Realizacja tego dążenia jest ułatwiona dzięki zatwierdzeniu przez Stolicę Apostolską księgi liturgicznej przeznaczonej dla ordynariatów personalnych o nazwie Divine Worship ${ }^{51}$. Księga ta „wyraża i zachowuje dla kultu katolickiego wartościowe dziedzictwo liturgiczne anglikańskie, przyjęte w tym wymiarze, w którym odżywiało katolicką wiarę w czasie całej historii anglikańskiej tradycji i przynaglało aspiracje do kościelnej jedności"52. Publiczne celebrowanie liturgii z użyciem Divine Worship

kodeksowym dotyczącym diecezji terytorialnych. Por. Statut Ordynariatu Polowego w Polsce, nr 9.

${ }^{49}$ Ta elastyczność przejawia się w podkreśleniu przez Spirituali militum Curae, że jurysdykcja ordynariusza wojskowego dosięga osób, które należą do ordynariatu „nawet wówczas, kiedy te znajdują się czasowo poza granicami swojego kraju” (SMC art. IV).

${ }^{50} \mathrm{AC}$ art. III.

${ }^{51}$ Por. Divine Worship. The missal. In according with Roman Rite, Catholic Truth society, London 2015. Na pierwszej stronie przytaczanej księgi znajduje się następujący zapis w kolorze czerwonym: "The celebration of Holy Mass for use in the Personal Ordinariates established under the Apostolic Constitution Anglicanorum Coetibus”. Natomiast na początku znajdują się dwa wstępy: „The general instruction of the Roman Missal” (s. 11-118), a następnie: „Divine worship: rubrical directory” (s. 119-134). To zestawienie bardzo dobrze ukazuje podwójny wymiar tej księgi, ale także celu ordynariatu personalnego: jedność z Kościołem rzymskim przy jednoczesnym uszanowaniu tradycji wywodzących się z anglikanizmu.

${ }^{52} \mathrm{NC}$ art. $15 \$ 1$ : ,gives expression to and preserves for Catholic worship the worthy Anglican liturgical patrimony, understood as that which ha nourished the Catholic faith throughout the history of the Anglican tradition and prompted aspirations towards ecclesial unity" (tłumaczenie w tekście własne). 
jest ograniczone do utworzonych personalnych ordynariatów zatwierdzonych przez Stolicę Apostolską ${ }^{53}$.

$\mathrm{Z}$ uwagi na specyfikę i cel działania, zupełnie inna jest też relacja obu typów ordynariatów do prawa międzynarodowego, wyznaniowego i relacji z władzami państwa. Ordynariat polowy działa przede wszystkim na terenie danego państwa, dla dobra jego żołnierzy i we współpracy z zarządzającymi i dowodzącymi siłami zbrojnymi. Dlatego od strony prawnej ordynariat ma niejednokrotnie odniesienie do umów $\mathrm{z}$ państwami ${ }^{54}$ i pozostaje $\mathrm{w}$ relacji do przepisów obowiązujących w danych siłach zbrojnych ${ }^{55}$. Niejednokrotnie też kapelani wojskowi przyjmują od władzy państwowej stopnie, uposażenie, a także emeryture ${ }^{56}$. Natomiast dla ordynariatu personalnego punktem odniesienia jest terytorium konferencji episkopatu ${ }^{57}$, nie zawsze utożsamiające się z terytorium danego państwa ${ }^{58}$. Ordynariat

\footnotetext{
${ }^{53}$ Por. NC art. $15 \$ 2$.

${ }^{54}$ Por. SMC art. I $\$ 1$ : „Z uwzględnieniem - tam, gdzie takowe istnieją - umów zawartych pomiędzy Stolicą Apostolską a państwami”. Por. także Konkordat między Stolicą Apostolską a Rzecząpospolitą Polską podpisany w Warszawie dnia 28 lipca 1993 r. (Dz. U. z 1998, nr 52, poz. 318), art. $16 \$ 1$. Odnośnie do konkordatu włoskiego zob. E. Busato, La Chiesa, lo stato e i militari. Studio comparato fra l'ordinamento canonico e quello italiano. Padova 1992, s. 269-274.

${ }^{55}$ Por. Decyzja nr 326/MON Ministra Obrony Narodowej z dnia 28 sierpnia 2006 r. w sprawie organizacyjnego usytuowania Ordynariatu Polowego w resorcie obrony narodowej oraz współpracy organów wojskowych z Ordynariatem Polowym (Dz. U. MON 2006 nr 16, poz. 202); Decyzja nr 13/MON Ministra Obrony Narodowej z dnia 27 stycznia 2014 r. w sprawie szczegółowego zakresu działania Ordynariatu Polowego (Dz. U. MON 2014, poz. 32).

${ }^{56}$ Por. Statut Ordynariatu Polowego w Polsce nr 15.

${ }^{57}$ Por. AC art. I $\$ 1$ : „erygowane są [...] w granicach terytorium określonej Konferencji Episkopatu". $\$ 2$ tego samego artykułu stanowi, że na terytorium danej konferencji episkopatu może zostać utworzonych także więcej ordynariatów.

${ }^{58}$ Wystarczy spojrzeć na casus Wielkiej Brytanii. Mamy do czynienia z ordynariatem wojskowym Zjednoczonego Królestwa i z ordynariatem personalnym Anglii i Walii, czyli mniejszego terytorium, nie ukonstytuowanym w osobne państwo, ale pokrywające się z jedną konferencją episkopatu. Por. CONGREGATIO PRO DOCTRINA FIDEI, Decree of erection of the personal ordinariate of Our Lady of Walsingham, AAS 103 (2011), s. 131, nr 6: „The Ordinary is a member by right of the Episcopal
} 
personalny nie ma szczególnych relacji z państwem, a jego duchowni nie są z zasady wynagradzani przez władze państwowe ${ }^{59}$.

Choć w obu omawianych strukturach władza ordynariusza ma charakter personalny, jednak tylko w przypadku biskupa polowego władza ta jest sprawowana także poza granicami okręgu ${ }^{60}$. Jest to związane z celem ordynariatu wojskowego, jakim jest towarzyszenie żołnierzom danego państwa, gdziekolwiek by się w tym czasie znajdowali. W przepisach dotyczących ordynariatów personalnych nie znajdujemy podobnej normy - są one dużo mocniej związane z terytorium dla którego powstały i władza ordynariusza nie sięga poza terytorium wyjąwszy przypadki i sytuacje przewidziane przez prawo powszechne lub naturę rzeczy.

Ordynariusz wojskowy posiada władzę własną ${ }^{61}$, podczas gdy ordynariusz dla byłych anglikanów - zastępczą ${ }^{62}$. Określenie jurysdykcji ordynariusza dla byłych anglikanów jako zastępczej nie wydaje się przypadkowe. Ta norma wynika prawdopodobnie z celu ordynariatu personalnego, jakim jest włącznie byłych wyznawców anglikanizmu do jedności katolickiej komunii, reprezentowanej przez biskupa Rzymu ${ }^{63}$. To właśnie w imieniu Papieża ordynariusz dla byłych anglikanów sprawuje swoją władzę. W tym kontekście należałoby zwrócić uwagę na postanowienia Konstytucji Apostolskiej Anglicanorum Coetibus, które mają zagwarantować pełnię wiary katolickiej, do której przystępują wierni pochodzący z anglikanizmu. Ordynariaty personalne dla byłych anglikanów są erygowane przez

Conference of England and Wales with deliberative vote of those cases in which is required in law".

${ }^{59}$ Przynajmniej jest tak dotychczas w trzech już istniejących ordynariatach personalnych. Co więcej, w przypadku Ordynariatu Anglii i Walii duchowni i wierni pochodzący z anglikanizmu mogą stracić wyraźne uprzywilejowanie, jakie mieli, działając w ramach Kościoła Anglii.

${ }^{60}$ Por. SMC art. IV nr 3.

${ }^{61}$ Por. SMC IV nr 3.

${ }^{62}$ Por. AC art. V lit. b).

${ }^{63}$ Wskazuje na to dopowiedzenie „zastępcza: sprawowana w imieniu Biskupa Rzymskiego" (AC art. V, lit. b). 
Kongregację Doktryny Wiary i jej podlegają ${ }^{64}$. Prawdopodobnie ma to związek ze szczególną rolą tej Kongregacji jako strażnika wiary katolickiej ${ }^{65}$. Ponadto w Konstytucji Apostolskiej zostało podkreślone, że „Katechizm Kościoła Katolickiego jest oficjalnym wyrazem wiary katolickiej wyznawanej przez członków Ordynariatu”66.

W tym samym duchu podkreślenia jedności z Ojcem Świętym należałoby odczytać fakt konieczności zgody Stolicy Apostolskiej na powołanie parafii personalnej ordynariacie dla byłych anglikanów ${ }^{67}$. Powyższa norma wyraźnie ogranicza uprawnienia ordynariusza personalnego $\mathrm{w}$ porównaniu $\mathrm{z}$ biskupem diecezjalnym, który może takie parafie powoływać bez żadnej konsultacji ze Stolicą Świętą ${ }^{68}$. W ordynariatach polowych kapelani wojskowi są zasadniczo traktowani na równi z proboszczami ${ }^{69}$. Parafie personalne $\mathrm{w}$ sensie ścisłym są rzadko erygowane, gdzie jednak są tworzone, dzieje się to na podstawie prawa powszechnego, bez uprzedniego pytania Stolicy Apostolskiej o zgodę ${ }^{70}$.

W ordynariacie polowym zarówno władza biskupa polowego jak i opieka duszpasterska kapelanów wojskowych są kumulatywne, czyli wspólne z władzą oraz obowiązkami i prawami miejscowego biskupa diecezjalnego, a także proboszcza terytorialnego ${ }^{71}$. Oznacza to, że osoby, które przynależą do ordynariatu polowego, są jednocześnie „ściśle związane także z Kościołem partykularnym, do którego należą

\footnotetext{
${ }^{64}$ Por. AC art. I $\$ 1$ oraz art. XI. Natomiast Ordynariaty wojskowe podlegają Kongregacji Biskupów oraz Kongregacji Ewangelizacji Narodów (por. SMC, art. XI).

${ }^{65}$ Por. Ioannes Paulus II, Costitutio Apostolica De Romana Curia Pastor Bonus, 28.06.1988, art. 48, AAS 80 (1988), s. 873.

${ }^{66} \mathrm{AC}$ art. I $\$ 5$.

${ }^{67}$ Por. AC art. VIII $₫ 1$.

${ }^{68}$ Por. Kan. 518 KPK: „Gdzie jednak jest to wskazane należy tworzyć parafie personalne ze względu na obrządek, język, narodowość wiernych jakiegoś terytorium albo z innej określonej racji”.

${ }^{69}$ Por. SMC art. VII.

${ }^{70}$ Najwięcej, ponad 70 parafii personalnych występuje w Ordynariacie Polowym w Polsce.

${ }^{71}$ Por. SMC art. IV nr 3 oraz art. VII.
} 
z tytułu zamieszkania lub obrządku"72. Tymczasem byli anglikanie są jedynie wiernymi ordynariatu personalnego. Jednocześnie trzeba podkreślić, że Konstytucja apostolska Anglicanorum Coetibus parokrotnie mówi o współpracy $\mathrm{z}$ duszpasterzami diecezjalnymi ${ }^{73}$, a jej normy uzupełniające także o współdziałaniu wiernych świeckich oraz konsekrowanych w dziełach duszpasterskich i charytatywnych $^{74}$. W tym ostatnim przypadku jest mowa o tym, że w sytuacji takiej współpracy w sprawach diecezjalnych lub parafialnych wierni „zależą od Biskupa diecezjalnego lub proboszcza miejsca, dlatego w tym przypadku władza tych ostatnich jest sprawowana w sposób łączny z władzą Ordynariusza i proboszcza ordynariatu"75. Choć mówi się tu o sprawowaniu władzy w sposób łączny, jednak dotyczy to konkretnych sytuacji współdziałania duszpasterskiego lub charytatywnego i nie oznacza jurysdykcji kumulatywnej ${ }^{76} \mathrm{w}$ sensie pełnej przynależności wiernych do diecezji lub parafii terytorialnej. Z drugiej strony elementem wspólnym jest wspomniana powyżej

${ }^{72}$ SMC art. IV nr 3. Zob. także Por. A. Viana, Territorialidad y personalidad..., s. 205-210. .

${ }^{73}$ Por. AC art.VI $\$ 4$ : „Kapłani inkardynowani do ordynariatu [...] powinni również umacniać więzy jedności z prezbiterium diecezji, na terenie której pełnią swoją posługę; będą musieli popierać wspólne inicjatywy i działalność duszpasterską i charytatywną, które mogą być przedmiotem umów zawartych między ordynariuszem i lokalnym biskupem diecezjalnym”. Zob. także AC art. VIII $₫ 2$.

${ }^{74}$ Por. NC art. 5, $\$ 4$ : „Lay faithful and members of Institutes of Consecrated Life and Societies of Apostolic Life, when they collaborate in pastoral or charitable activities, whether diocesan or parochial, are subject to the Diocesan Bishop or to the pastor of the place $[\ldots]$ ".

${ }^{75} \mathrm{NC}$ art. $5 \S 4$ : „when they collaborate in the pastoral or charitable activities, whether diocesan or parochial, are subject to the Diocesan Bishop or to the pastor of the place; in which case the power of the Diocesan Bishop or pastor is exercised jointly with that of the Ordinary and the pastor of the Ordinariate" (w tekście tłumaczenie własne).

${ }^{76}$ Można dostrzec to także w angielskim oraz włoskim tekście cytowanych powyżej norm uzupełniających, gdzie jest mowa o władzy sprawowanej „jointly”, a po włosku „in modo congiunto”. Wydaje się, że prawodawca świadomie nie używa technicznego słowa dotyczącego władzy kumulatywnej - „cumulativo”. 
możliwość uzupełniającej posługi proboszcza terytorialnego wobec wiernych parafii personalnej kiedy proboszcz personalny ma przeszkodę w działaniu ${ }^{77}$.

Choć prawo powszechne daje w konkretnych sytuacjach władzę nad wiernymi ordynariatu ordynariuszowi lub proboszczowi terytorialnemu, wydaje się słuszna teza, że przynależność wiernych do ordynariatu dla byłych anglikanów jest ekskluzywna ${ }^{78}$. Nie ulega wątpliwości, że wierni ordynariatu personalnego są przede wszystkim członkami tej struktury hierarchicznej. Ordynariat personalny dla wiernych przychodzących z anglikanizmu jest Kościołem partykularnym do którego wierni w pierwszym rzędzie przynależą, co podkreśla specyfikę tego kościelnego okręgu. Ma to również wymiar praktyczny i ekumeniczny, gdyż są to wierni, którzy przychodzą ze wspólnoty anglikańskiej, nie mający uprzednio żadnych więzi kanonicznych z Kościołem katolickim. Nie zostają więc przymuszeni przez prawo kościelne, aby przynależeć do innej struktury hierarchicznej niż ordynariat personalny, który gwarantuje im szacunek dla ich tradycji liturgicznych i duchowych.

Podobną różnicę widać w kształcie prezbiterium obu instytucji: prezbiterium ordynariatu polowego składa się zarówno z księży inkardynowanych, jak i tych, którzy dla dobra danego ordynariatu pełnią stałą posługę ${ }^{79}$. Oddelegowanie odpowiednich księży do posługi

\footnotetext{
${ }^{77}$ Por. NC art. $14 \$ 2$ : „If there is no vicar, in the event of absence, incapacity, or death of a pastor, the pastor of the territorial parish in which the church of the personal parish is located can exercise his faculties as pastor so as to supply what is needed".

${ }^{78}$ Por. G. Ghirlanda, La Costituzione Apostolica..., s. 412-413; P. ZaJĄC, Status prawny Ordynariatów personalnych..., s. 73. Inaczej Majer, który nie przesądza natury jurysdykcji oraz Arrieta, który wprost twierdzi, że wierni należą do diecezji na której terenie mają zamieszkanie. Por. J.I. ArrietA, Gli ordinariati..., s. 166-167; P. Majer, Nowa hierarchiczna struktura..., s. 362.

${ }^{79}$ Por. Statut Ordynariatu Polowego w Polsce, nr 10: „Prezbiterium Ordynariatu Polowego tworzą duchowni diecezjalni i zakonni inkardynowani do Ordynariatu lub wykonujący dla dobra tegoż jakiś stały obowiązek (por. kan. $498 \$ 1$, nr 2)”. W Ordynariacie Polowym w Polsce większość na stałe posługujących kapelanów jest inkardynowana do swoich diecezji i zakonów.
} 
w ordynariacie polowym jest obowiązkiem biskupów i przełożonych zakonnych $^{80}$. Taka złożona struktura prezbiterium ordynariatu polowego jest zgodna z jego zadaniami, gdyż przy jurysdykcji kumulatywnej wymaga się od kapelanów dobrej znajomości prezbiterium diecezjalnego i umiejętności współpracy ${ }^{81}$. Tymczasem w ordynariacie personalnym prezbiterium stanowią jedynie księża inkardynowani do niego, zasadniczo poprzez święcenia, zarówno duchownych pochodzących z anglikanizmu, jak i nowo uformowanych kleryków, święconych dla ordynariatu personalnego ${ }^{82}$. Takie rozwiązanie pozwala ordynariuszowi na podkreślenie specyfiki posługi kapłańskiej w ordynariacie personalnym i zadbanie o jego tożsamość.

W ordynariacie polowym każdy ordynariusz ma prawo do utworzenia własnego seminarium duchownego, w którym klasyczna formacja kapłańska byłaby dopełniona przez szczególną formację duchową i duszpasterską ${ }^{83}$. Natomiast w ordynariacie personalnym dla byłych anglikanów, mogą zostać także utworzone osobne domy dla alumnów ordynariatu, jednak mają być związane „z już istniejącymi wydziałami teologicznymi" ${ }^{44}$. Kandydaci do święceń w ordynariacie personalnym dla byłych anglikanów mają formować się wspólnie z innymi klerykami, „zwłaszcza w zakresie doktrynalnym i duszpasterskim" ${ }^{85}$. Szczególny nacisk na aspekt doktrynalny wynika prawdopodobnie ze specyfiki ordynariatów personalnych, jako narzędzi powrotu do pełnej jedności wiary. Kształcenie alumnów w ordynariatach personalnych ma spełnić dwa kryteria: „1) formacja złączona z seminarzystami diecezjalnymi zgodnie z miejscowymi warunkami; 2) formacja, w pełnej harmonii z tradycją katolicką, w pewnych aspektach dziedzictwa anglikańskiego o specjalnej wartości" ${ }^{\prime 26}$. Mając na uwadze ten ostatni cel „formacji w zakresie dziedzictwa

\footnotetext{
${ }^{80}$ Por. SMC art. VI.

${ }^{81}$ Por. A. Viana, Territorialidad y personalidad..., s. 177-191.

${ }^{82}$ Por. AC art. VI nr 3-5.

${ }^{83}$ Por. SMC art. VI $\$ 3$.

${ }^{84} \mathrm{AC}$ art. VI $\$ 5$.

${ }^{85} \mathrm{AC}$ art. VI $\$ 3$.

${ }^{86} \mathrm{NC}$ art. $10 \$ 1$ (tłumaczenie własne).
} 
anglikańskiego, ordynariusz może wprowadzić odpowiednie programy seminaryjne" 87 .

Równowaga pomiędzy szacunkiem dla tradycji anglikańskiej, a potrzebą jej integracji z porządkiem kanonicznym Kościoła katolickiego jest zachowana również w delikatnym punkcie dotyczącym zakresu obowiązywania prawa celibatu kapłańskiego. Z zasady będą dopuszczani do święceń kapłańskich tylko ci kandydaci, którzy zobowiążą się do zachowania celibatu. Jednak wyjątkowo ordynariusz może dopuścić do święceń prezbiteratu żonatych mężczyzn. Ta ostatnia klauzula nie dotyczy wyłącznie byłych duchownych anglikańskich, ale także, za zgodą Papieża i w poszczególnych przypadkach, także innych viri probati ${ }^{88}$.

W Ordynariacie polowym już w konstytucji apostolskiej Spirituali Militum Curae jest przewidziane powołanie rady kapłańskiej ${ }^{89}$, a w poszczególnych statutach są także przepisy odnośnie do innych ciał kolegialnych ${ }^{90}$, których funkcjonowanie odbywa się na zasadach zawartych w Kodeksie prawa kanonicznego. Tymczasem w ordynariatach dla byłych anglikanów kluczową rolę odgrywa specyficzne gremium, jakim jest Rada Zarządzająca, która spełnia jednocześnie rolę rady kapłańskiej i kolegium konsultorów przewidzianych w Kodeksie prawa kanonicznego ${ }^{91}$, ale otrzymała znacznie większe kompetencje ${ }^{92}$. Zgoda Rady Zarządzającej jest wymagana przy dopuszczaniu kandydatów do święceń kapłańskich ${ }^{93}$, utworzeniu lub zniesieniu parafii personalnej lub domu formacyjnego oraz zatwierdzeniu

\footnotetext{
${ }^{87}$ AC art. VI $\$ 5$.

${ }^{88}$ Por. AC art. VI $\$ 1-2$.

${ }^{89}$ Por. SMC art. VI $\$ 3$.

${ }^{90}$ Zob. Statut Ordynariatu Wojskowego czyli Polowego w Polsce, nr 16.

${ }^{91}$ Por. AC art. X $\$ 1-2$

${ }^{92}$ Por. AC art. X, $\$ 2$ : „Rada zarządzająca [...] pełni funkcje ustalone przez Kodeks Prawa Kanonicznego dla Rady Kapłańskiej i Kolegium Konsultorów, jak również te, które zostały wyszczególnione w Normach Uzupełniających”.

${ }^{93}$ Por. NC art. $12 \$ 2$ : „The Ordinary needs the consent of the Governing Council to 1 . admit a candidate to Holy Orders".
} 
programu formacyjnego ${ }^{94}$. Rada Zarządzająca dysponuje ponadto samodzielnym głosem decydującym w tak istotnych sprawach, jak przygotowanie dla Stolicy Świętej listy kandydatów na ordynariusza $^{95}$, zaproponowanie zmian w normach uzupełniających danego ordynariatu w celu przedstawienia ich Stolicy Apostolskiej, a także opracowanie statutu samej rady zarządzającej, rady duszpasterskiej oraz regulaminu domu formacyjnego ${ }^{96}$. W ten sposób w ordynariacie dla byłych anglikanów jest zagwarantowana dużo większa kolegialność w rządzeniu, niż w zwykłej diecezji terytorialnej Kościoła łacińskiego. Na szczególną uwagę zasługuje uprawnienie przesyłania trzech kandydatów na ordynariusza, które jest wyraźnym znakiem współpracy Rady Zarządzającej ze Stolicą Apostolską według najlepszych kanonicznych wzorców ${ }^{97}$.

\section{Wnioski}

Jak wynika z powyższych rozważań, różnice między ordynariatami polowymi a ordynariatami personalnymi są bardziej widoczne niż podobieństwa. Jednak należałoby podkreślić, że podobieństwa są w niektórych bardzo podstawowych sprawach, natomiast różnice wynikają z odmiennych zadań obu struktur personalnych. Struktura ordynariatu personalnego jest niezwykle elastyczna i obiecująca. Posiada pewne elementy uniwersalne, ale także wiele rozwiązań, które można dostosować do celów, jakie będą stały przed kolejnymi

\footnotetext{
${ }^{94}$ Por. NC art. $12 \S 2:$ „2. erect or suppress a personal parish; 3. erect or suppress a house of formation 4 . approuve a program of formation”. Według norm kodeksowych, do stworzenia lub zniesienia parafii jest potrzebne wysłuchanie Rady Kapłańskiej, ale nie jej zgoda (por. kan. $515 \mathrm{KPK}$ ). W pozostałych wymienionych sprawach biskup diecezjalny może działać zupełnie samodzielnie, natomiast ordynariusz personalny potrzebuje zgody Rady Zarządzającej.

${ }^{95}$ Por. NC art. $12 \$ 4$ : „, The Governing Council has a deliberative vote: 1 . when choosing a terna of names to submit to the Holy See for the appointment of the Ordinary".

${ }^{96}$ Por. NC art. $12 \$ 4$, nr 2-4.

${ }^{97}$ Zob. L. Gerosa, Interpretacja Prawa w Kościele. Zasady. Wzorce. Perspektywy, Kraków 2003, s. 214-218.
} 
strukturami o tym charakterze. Dzisiejsza mobilność, spotkanie kultur i tradycji, a także szacunek dla odrębności i własnego prawa, sprawia, że prawdopodobnie żywotność i adekwatność kościelnych struktur personalnych w przyszłości będzie coraz większa ${ }^{98}$.

\section{The Military Ordinariate and the personal ordinariate for former Anglicans - similarities and differences}

This study has been inspired by the intuition that the concept of personal ordinariate can be applied to various situations in the Church and seems to be very promising for the pastoral care in many exceptional situations. In fact, this juridical structure laid base for the pastoral care for the military and later was used to offer former Anglicans the possibility of entering full communion with the Catholic Church without losing their own customs and traditions.

The article is divided into three parts. The first outlines the development of the concept of legal personal structures in the 20th century, especially from the $2^{\text {nd }}$ Vatican Council. In the second part there are going to be presented major elements of the Military Ordinariate that were to be later used in the personal ordinariate for the former Anglicans. In the third part one will find key differences and new legal solutions designed exclusively for the personal ordinariate for those coming from Anglicanism.

The study shows the significance of the juridical structures of personal ordinariate that in the future can be applied to another new pastoral needs in the changing world.

SŁOWA KLUCzowe: struktura personalna; ordynariat wojskowy; ordynariat personalny; troska duszpasterska

KEYWORDS: personal structure; military ordinariate; personal ordinariate; pastoral care

\footnotetext{
${ }^{98} \mathrm{Na}$ uwagę zasługuje powołanie już przez papieża Franciszka w 2016 roku Ordynariatu dla katolików obrządków wschodnich nie posiadający własnego ordynariusza w Hiszpanii Por. Congregatio pro Ecclesirs orientalibus, Dekret Noblis Hispaniae Natio, 9.06.2016, Ius canonicum, 56 (2016), s. 769-770.
} 


\section{Nota o Autorze}

Ks. DR JAN Dohnalik - adiunkt na Wydziale Prawa Kanonicznego Uniwersytetu Kardynała Stefana Wyszyńskiego w Warszawie, kanclerz Kurii Biskupiej Ordynariatu Polowego w Polsce. 